\title{
Effect of Terminal Design and Bipolar Plate Material on PEM Fuel Cell Performance
}

\author{
Yue Hung ${ }^{1}$, Hazem Tawfik ${ }^{1,2}$, Devinder Mahajan ${ }^{2,3}$ \\ ${ }^{1}$ Department of Mechanical Engineering Technology, Farmingdale State College, New York, USA; ${ }^{2}$ Department of Materials Sci- \\ ence and Engineering, Stony Brook University, Stony Brook, USA; ${ }^{3}$ Energy Sciences \& Technology Department, Brookhaven Na- \\ tional Laboratory, New York, USA. \\ Email: Jeff.hung@farmingdale.edu
}

Received November $18^{\text {th }}, 2012$; revised December $18^{\text {th }}, 2012$; accepted December $25^{\text {th }}, 2012$

\begin{abstract}
Bipolar plates perform as current conductors between cells, provide conduits for reactant gases, facilitate water and thermal management through the cells, and constitute the backbone of a fuel cell stack. Currently, commercial bipolar plates are made of graphite composite because of its relatively low interfacial contact resistance (ICR) and high corrosion resistance. However, graphite composite's manufacturability, permeability, and durability of shock and vibration are unfavorable in comparison to metals. Therefore, metals have been considered as a replacement material for graphite composite bipolar plates. The main objective of this study is to evaluate the effect of terminal connection design and bipolar plate material on PEM fuel cell overall performance. The study has indicated that single cell performance can be improved by combining terminals into metallic bipolar plates. This terminal design reduces the internal cell resistance and eliminates the need for additional terminal plates. The improved single cell performance by $18 \%$ and the increased savings in hydrogen consumption by $15 \%$ at the current density of $0.30 \mathrm{~A} / \mathrm{cm}^{2}$ was attributed to the robust metal to metal contact between the terminal and the metallic bipolar plates. However, connecting metal terminal directly into graphite bipolar plates did not exhibit similar improvement in the performance of graphite fuel cells because of their brittleness that could have caused damage in the plates and poor contacts.
\end{abstract}

Keywords: PEM Fuel Cell; Metallic Bipolar Plate; Cell Internal Resistance; Terminal Design

\section{Introduction}

Fuel cells have the potential of providing advantages in efficiency, reliability, cost effectiveness, clean environment, and reducing our national dependence on fossil fuel. In particular, polymer electrolyte membrane (PEM) fuel cells operate at relatively low temperature of $80^{\circ} \mathrm{C}$ or less, have high power density, can vary their power output quickly to meet the shifting power demand, and are suited for automobiles, where quick startup is necessary [1-4]. PEM fuel cell is recognized by the US Department of Energy (DOE) as the main candidate to replace the internal combustion engine in transportation applications. Bipolar plates and membrane electrode assembly (MEA) are the two main components of a PEM power stack. PEM fuel cell powered by hydrogen can produce over $53 \%$ electrical efficiency and if the system heat recovery is considered, the overall efficiency can exceed $80 \%$. In comparison, the efficiencies of most mechanical and electrical energy sources used today range from $15 \%$ to $30 \%$. A key requirement for power application used in automotive industry is the production of compact and lightweight PEMFC power system, which may be achieved by proper selection of materials.

Currently, durability and cost represent two main challenges hindering the fuel cell technology from penetrating the energy market and competing with other energy systems. Thus, considerable attention has been recently given to metallic bipolar plates for their particular suitability to transportation applications. Metals enjoy higher mechanical strength, better durability to shocks and vibration, no permeability, and much superior manufacturability and cost effectiveness when compared to carbon-based materials, namely carbon-carbon and carbon-polymer composites [5-7]. However, the main handicap of metals is the lack of ability to combat corrosion in the harsh acidic and humid environment inside the PEM fuel cell without forming oxidants, passive layers, and metal ions that could cause considerable power degradation.

Metallic bipolar plates can be classified into coated and non-coated metals. Tawfik et al. [8] and Antunes et al. [9] conducted a comprehensive survey in metallic bipolar plate materials that have been utilized by many 
researchers. Most of the metal bipolar plate research focuses on stainless steel materials and the goal is to improve the corrosion resistance and surface conductivity of the materials. For example, Wang et al. [10,11] found that both austenitic (349 TM) and ferritic (AISI446) stainless steel with high $\mathrm{Cr}$ content showed good corrosion resistance and could be suitable for bipolar plate application, though AISI446 requires some improvement in ICR due to the formation of a surface passive layer of $\mathrm{Cr}_{2} \mathrm{O}_{3}$. The researchers also verified that $\mathrm{Cr}$ in the alloy was responsible of forming passive film on the surface of stainless steel. As the $\mathrm{Cr}$ content in stainless steel increased, the corrosion-resistance improved as it is commonly known in the corrosion field. However, a thick non-conductive surface passive layer of $\mathrm{Cr}_{2} \mathrm{O}_{3}$ will produce an undesirable high ICR. The authors recommended that further improvement in the ICR would require some modification of the passive film, which was dominated by chromium oxide.

Yang et al. [12] developed the lower temperature chromizing treatment to modify $316 \mathrm{~L}$ stainless steel for bipolar plate application. Their results shows that the chromized SS $316 \mathrm{~L}$ exhibits better corrosion resistance and lower ICR value than those of bare SS $316 \mathrm{~L}$. The passive current density of the chromized SS $316 \mathrm{~L}$ is approximately $3 \times 10^{-7} \mathrm{~A} \cdot \mathrm{cm}^{-2}$ that is about four orders of magnitude lower than that of bare SS $316 \mathrm{~L}$. The ICR value of the chromized SS $316 \mathrm{~L}$ is $13 \mathrm{~m} \Omega \cdot \mathrm{cm}^{2}$ that is about one-third of bare SS $316 \mathrm{~L}$ at $200 \mathrm{~N} \cdot \mathrm{cm}^{-2}$ compaction forces. Fu et al. [13] studied Cr-nitride films on stainless steel $316 \mathrm{~L}$. Their work confirmed that after potentiodynamic and potentiostatic tests in both simulated anodic and cathodic environment at $70^{\circ} \mathrm{C}$, the corrosion resistance of Cr-nitrided SS $310 \mathrm{~L}$ sample was greatly enhanced in comparison to the uncosted SS $316 \mathrm{~L}$ sample. The interfacial contact resistance between the Cr-nitrided SS $316 \mathrm{~L}$ sample and the Toray carbon paper was about two orders of magnitude lower than that of the untreated SS $316 \mathrm{~L}$. In addition, this group indicated that the contact angle of the Cr-nitrided sample with water was $95^{\circ}$, which is beneficial for water management in fuel cell.

In addition to stainless steel materials, aluminum is also considered as a substrate material for bipolar plate by other researchers. Abo El-Enin et al. [6] and Fetohi et al. [14] applied several nickel based alloys on aluminum 1050 and 5251 substrates to improve the corrosion resistance of the aluminum. The result of corrosion testing seems to be promising for fuel cell bipolar plate application. However, durability test results of these nickel based coating materials were not reported. Previous studies conducted by Hung et al. $[15,16]$ demonstrated that single fuel cells made of surface treated aluminum bipolar plates had successfully operated for 1000 hours at $70^{\circ} \mathrm{C}$ without significant power degradation. The study also showed that the surface treated aluminum bipolar plates provided approximately $12 \%$ and $22 \%$ savings in hydrogen consumption at the operating temperature of $20^{\circ} \mathrm{C}$ and $70^{\circ} \mathrm{C}$, respectively, in comparison to the graphite composite plate. It was due to the lower cell resistance of the aluminum cells. Bipolar plate materials certainly affect the cell resistance; however, other design considerations, such as location of the terminals, also affect the cell performance. Therefore, the main objective of this study is to evaluate the effect of terminal connection design and bipolar plate material Interface Contact Resistance (ICR) on the PEM fuel cell performance.

\section{Experimental Work}

In the current study, two single fuel cells with $50 \mathrm{~cm}^{2}$ active area were machined identically to investigate the effect of bipolar plate material and terminal design on fuel cell performance and power output at the single-cell level. One of these single cells was made of coated aluminum bipolar plates and the other was made of graphite composite plates as a control reference as shown in Figure 1. The aluminum single cell was coated with chromium carbide $\left(\mathrm{Cr}_{3} \mathrm{C}_{2}\right)$ based coating utilizing High Velocity Oxygen Fuel (HVOF) thermal spray process to prevent corrosion on the bipolar plates. The graphite composite blank plates were acquired from Bulk Molding Compound Inc.

The single cells were designed to adopt two different terminal designs for comparison of power output and design optimization. The first terminal design consisted of metal screws directly mounted into the bipolar plates to stimulate the one piece terminal/bipolar plate design and to reduce the need for two extra front and back terminal plates as shown in Figure 2(a). Gold plated stainless steel plates were utilized as the second terminal design to reduce the possibility of surface corrosion and to sandwich the bipolar plates together as shown in Figure 2(b). Membrane electrode assemblies used in the $50 \mathrm{~cm}^{2}$

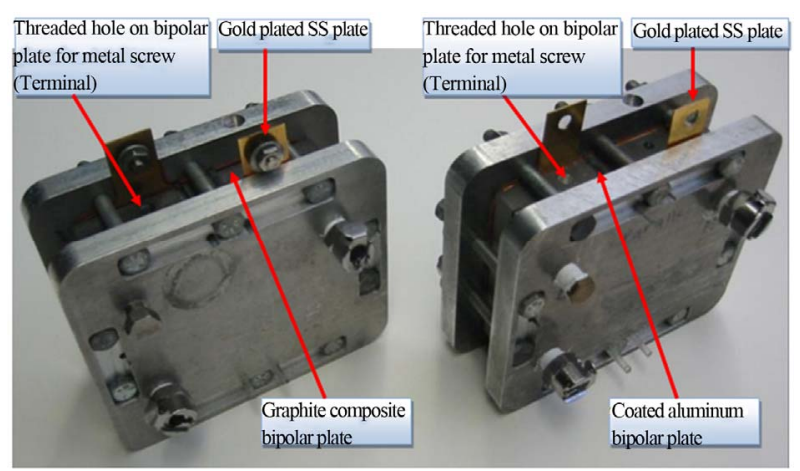

Figure 1. Graphite composite and coated aluminum single cells $\left(50 \mathrm{~cm}^{2}\right.$ active area). 


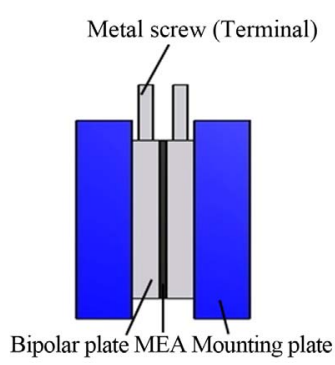

(a)

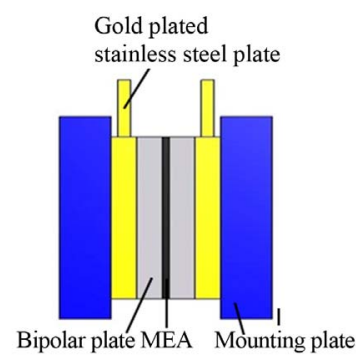

(b)
Figure 2. Structures of single fuel cell with different terminal designs (a) Directly mounted terminals (b) Gold plate terminal plates.

active area fuel cell were obtained from BASF Inc. series ES12E-W-5L with the proprietary Pt loading.

Two single fuel cells were operated under identical controlled temperature of $20^{\circ} \mathrm{C}$, air flow rate of $1.8 \mathrm{SLM}$, air and hydrogen pressure of $0.034 \mathrm{MPa}(5 \mathrm{psig})$ for performance testing and comparison. The hydrogen was dead-ended at the exhaust manifold for these cells. In addition, the fuel cells operated with compress air obtained from an industrial compressor and dry industrial grade hydrogen supplied from a metal hydride storage tank. All operating parameters, such as current, voltage, and power as well as temperature, back pressure and reactant gases volume flow rate were measured and recorded. Polarization power output and hydrogen consumption curves were measured and plotted for comparison using the programmable electronic load (MCL 488 DYNALoad) and reactant gas volume flow meters.

\section{Results and Discussion}

Fuel cell performance can be greatly affected by the cell internal resistance. Different bipolar plate materials and fuel cell terminal structure designs can affect the cell internal resistance. Figure 3 shows the cell internal resistance measurement of $50 \mathrm{~cm}^{2}$ active area single cells with different bipolar plate materials namely coated aluminum and graphite composite. For quantitative investigation of the cell internal resistance, excluding the electrical resistance of the Nafion membrane, the MEAs were simply replaced by a layer of gas diffusion layer (GDL) in these single cells. Two different terminal designs as shown in Figures 2(a) and (b) were also included in the test. Figure 3 shows that the internal resistance measurements of the coated aluminum and graphite composite cells with the gold plated terminal plate design were 6.62 mohm and $6.82 \mathrm{mohm}$, respectively. The internal resistances of both fuel cells with such terminal design were relatively close with $0.3 \%$ difference. However, the resistance measurements of the coated aluminum and graphite composite cells with the directly mounted terminal on the bipolar plates were $3.56 \mathrm{mohm}$ and 18.52 mohm, respectively.

The advantage of using the bipolar plate directly as a terminal is to eliminate the existence of additional internal electrical resistance in the cell due to the extra terminal plates. In addition, the directly mounted terminal design in the coated aluminum single cell showed a $46 \%$ reduction of cell internal resistance in comparison to the gold plated terminal plate design as shown in Figure 3. This was due to the low contact resistance between the metal screw terminal and the aluminum plate as the screw was tightly in contact with the coated aluminum plate. However, the brittleness of the graphite composite plate caused a lack of tight contact between the plate and the metal screw terminal, resulting in poor contact resistance between them and showing an increase of $520 \%$ in cell internal resistance in comparison to the coated aluminum plate. Therefore, it is not recommended to have terminals directly mounted on the graphite composite because the graphite bipolar plates could be damaged under load due to their weak mechanical strength.

To further investigate the cell performance with different bipolar plate materials and terminal designs, two $50 \mathrm{~cm}^{2}$ active area single cells made of coated aluminum and graphite composite plates, as shown in Figure 1, were examined. Figure 4 shows the polarization curves and power curves of both single cells with the gold plated terminal plate design at operating temperature of $20^{\circ} \mathrm{C}$. As expected, since the cell internal resistance of these two cells was similar, their performance and peak power density were almost the same at approximately $0.115 \mathrm{~W} / \mathrm{cm}^{2}$. However, coated aluminum bipolar plate combined with the directly mounted terminal design enhanced the maximum power density to $0.135 \mathrm{~W} / \mathrm{cm}^{2}$ as shown in Figure 5. This increase in the power density was due to the lower cell internal resistance between the two metal bipolar plates with the directly mounted terminals as demonstrated in Figure 3. The results obtained

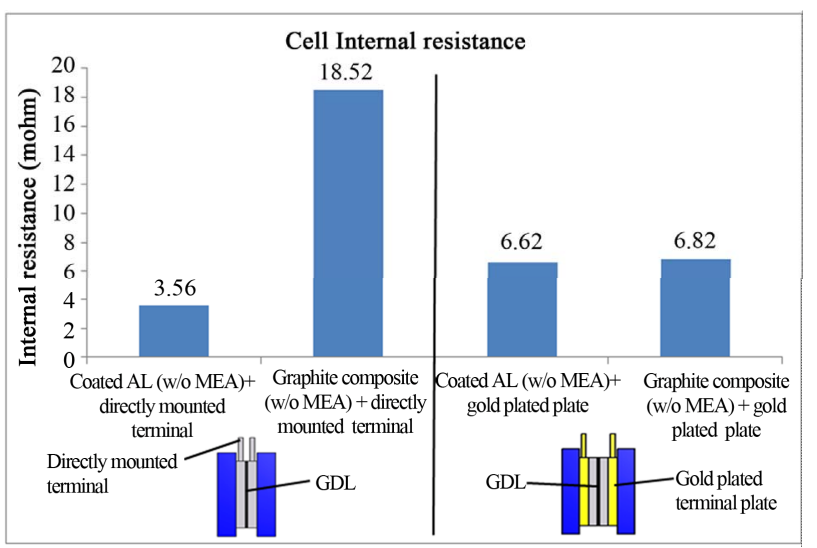

Figure 3. Internal resistance of $50 \mathrm{~cm}^{2}$ single cells at clamping pressure $\left(200 \mathrm{~N} / \mathrm{cm}^{2}\right)$ (the MEA is replaced by a GDL). 
from both single cells have also exhibited that at the same operating current density, higher voltage and power output can be achieved by using the directly mounted terminal design on coated aluminum single cell. For example, when both single fuel cells operated at the current density of $0.30 \mathrm{~A} / \mathrm{cm}^{2}$, the graphite composite and aluminum coated cells produced the power density of 0.110 $\mathrm{W} / \mathrm{cm}^{2}$ and $0.130 \mathrm{~W} / \mathrm{cm}^{2}$, respectively as shown in Figure 5. This represents $18 \%$ increase in performance. Moreover, these two respective cells had also produced voltage at the level of $0.367 \mathrm{~V}$ and $0.45 \mathrm{~V}$ at the current density of $0.30 \mathrm{~A} / \mathrm{cm}^{2}$. The advantage of producing higher voltage or power output from each cell at the same current density is that the coated aluminum cell with a higher power output have proven to be more efficient than the graphite composite cell because hydrogen consumption was the same for both cells and was almost linearly proportional to the current density.

Figure 6 shows that hydrogen consumption per watt for coated aluminum single cell using a threaded terminal design was less than that for the graphite composite single cell using a gold plated end plate design. For example, at the current density of $0.30 \mathrm{~A} / \mathrm{cm}^{2}$, the hydrogen consumption per watt was $16.2 \mathrm{SCCM} / \mathrm{W}$ and $19.1 \mathrm{SCCM} /$ $\mathrm{W}$ for coated aluminum and composite graphite single cells, respectively. This represents $15 \%$ savings in hydrogen consumption at $0.30 \mathrm{~A} / \mathrm{cm}^{2}$ when coated aluminum bipolar plates with directly mounted terminals were used.

The results from the $50 \mathrm{~cm}^{2}$ active area single cells demonstrates that combining terminal into metallic bipolar plate can enhance the power density of a fuel cell in comparison to the gold plated end plate terminal design. In addition, due to excellent mechanical strength of the metallic bipolar plate and lack of brittleness, terminal can

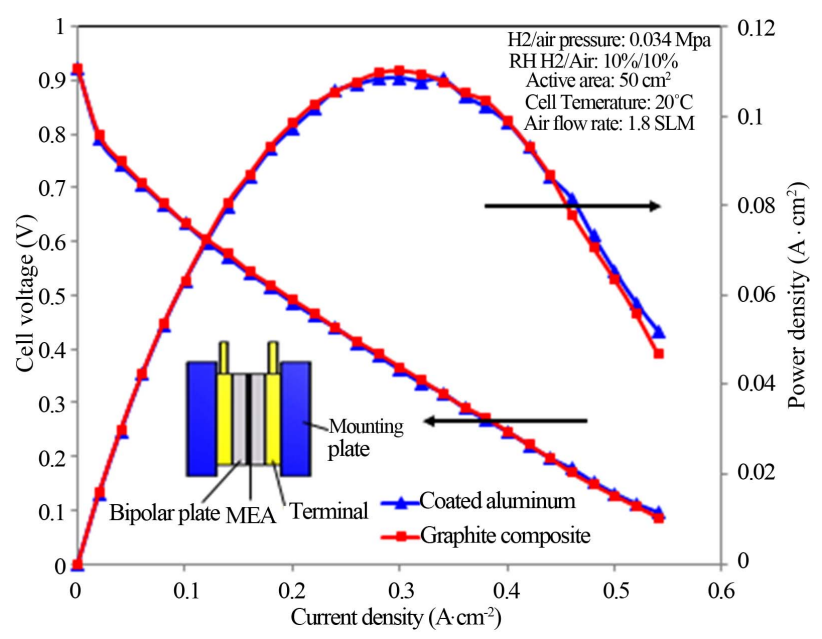

Figure 4. Polarization curve and power density curve comparison of $50 \mathrm{~cm}^{2}$ active area single cells with end plate terminal design at clamping pressure $\left(200 \mathrm{~N} / \mathrm{cm}^{2}\right)$.

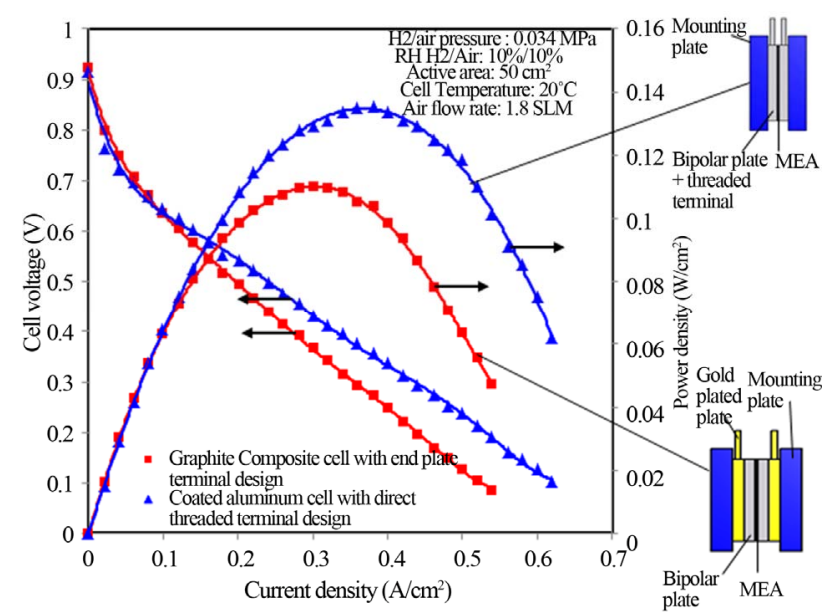

Figure 5. Polarization curve and power density curve comparison between graphite composite single cell with end plate terminal design and coated aluminum single cell with directly threaded terminal design at clamping pressure (200 $\mathrm{N} / \mathbf{c m}^{2}$ ).

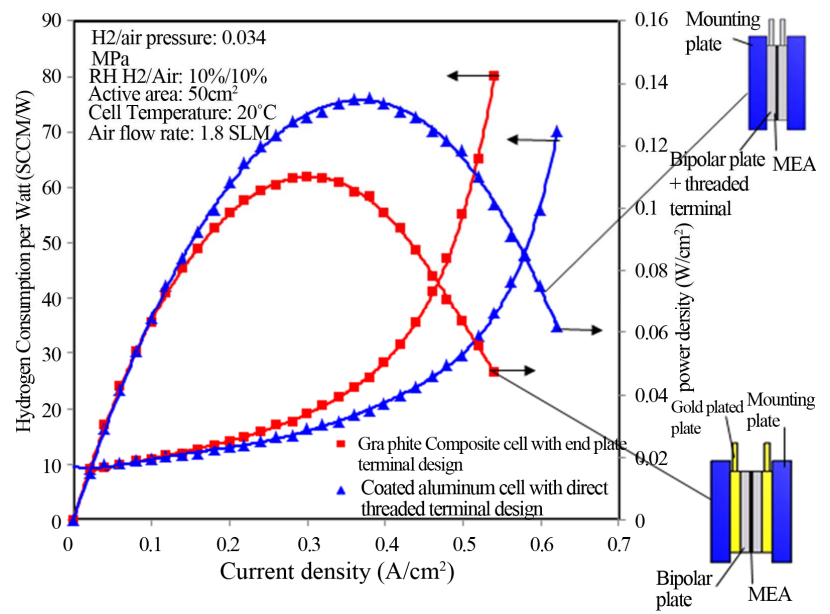

Figure 6. Power density curve and hydrogen consumption per watt comparison between graphite composite single cell with end plate terminal design and coated aluminum single cell with directly mounted terminal design at clamping pressure $\left(200 \mathrm{~N} / \mathrm{cm}^{2}\right)$.

be mounted directly into the bipolar plate to reduce the need for extra terminal plates. However, due to the brittleness of the graphite composite plates, mounting terminals on to graphite plate were unfeasible. Accordingly, one of the most considerable disadvantages of graphite or graphite composite compared to metal is their high brittleness.

\section{Conclusion}

Combining terminals into bipolar plates is proven to improve the efficiency of a fuel cell in comparison to the commonly used end plate terminal design. In addition, it can reduce the need of two extra front and back terminal 
plates and reduce the capital cost of the fuel cell. However, only metallic bipolar plates can benefit from the use of this terminal design due to their ductility, lack of brittleness, and suitability for anchoring the metal terminals directly to the plates forming a highly conductive terminal assembly. The graphite composite bipolar plates, on the other hand, are brittle that can cause cracking and/or mechanical failure under the high tightening force when terminals are directly mounted onto bipolar plates. The metallic single cell's setup can reduce hydrogen consumption by about $15 \%$ and can increase cell performance by approximately $18 \%$.

\section{REFERENCES}

[1] C. Turan, O. N. Cora and M. Koc, "Effect of Manufacturing Processes on Contact Resistance Characteristics of Metallic Bipolar Plates in PEM Fuel Cells," International Journal of Hydrogen Energy, Vol. 36, No. 19, 2011, pp. 12370-12380. doi:10.1016/j.ijhydene.2011.06.091

[2] Y. X. Liu and L. Hua, "Fabrication of Metallic Bipolar Plate for Proton Exchange Membrane Fuel Cells by Rubber Pad Forming," Journal of Power Sources, Vol. 195, No. 11, 2010, pp. 3529-3535. doi:10.1016/j.jpowsour.2009.12.046

[3] F. Barbir, "PEM Fuel Cells," Elsevier Academic Press, Amsterdam, 2005.

[4] M. M. Mench, "Fuel Cell Engines," Wiley, Chichester, 2008. doi:10.1002/9780470209769

[5] C.-Y. Bai, M.-D. Ger and M.-S. Wu, "Corrosion Behaviors and Contact Resistances of the Low-Carbon Steel Bipolar Plate with a Chromized Coating Containing Carbides and Nitrides," Int. J. Hydrogen Energy, Vol. 34, No. 16, 2009, pp. 6778-6789.

doi:10.1016/j.ijhydene.2009.05.103

[6] S. A. A. El-Enin, O. E. Abdel-Salam, H. El-Abd and A. M. Amin, "New Electroplated Aluminum Bipolar Plate for PEM Fuel Cell," Journal of Power Sources, Vol. 177, No. 1, 2008, pp. 131-136.

doi:10.1016/j.jpowsour.2007.11.042

[7] D. M. Zhang, L. T. Duan, L. Guo and W.-H. Tuan, "Corrosion Behavior of TiN-Coated Stainless Steel as Bipolar Plate for Proton Exchange Membrane Fuel Cell," International Journal of Hydrogen Energy, Vol. 35, No. 8, 2010, pp. 3721-3726. doi:10.1016/j.ijhydene.2010.01.043
[8] H. Tawfik, Y. Hung and D. Mahajan, "Metal Bipolar Plates for PEM Fuel Cell-A Review," Journal of Power Sources, Vol. 163, No. 2, 2007, pp. 755-767. doi:10.1016/i.jpowsour.2006.09.088

[9] R. A. Antunes, M. C. L. Oliveira, G. Ett and V. Ett, "Corrosion of Metal Bipolar Plates for PEM Fuel Cells: A Review," International Journal of Hydrogen Energy, Vol. 35, No. 8, 2010, pp. 3632-3647. doi:10.1016/j.ijhydene.2010.01.059

[10] H. L. Wang, M. A. Sweikart and J. A. Turner, "Stainless Steel as Bipolar Plate Material for Polymer Electrolyte Membrane Fuel Cells," Journal of Power Sources, Vol. 115, No. 2, 2003, pp. 243-251. doi:10.1016/S0378-7753(03)00023-5

[11] H. L. Wang and J. A. Turner, "Ferritic Stainless Steels as Bipolar Plate Material for Polymer Electrolyte Membrane Fuel Cells," Journal of Power Sources, Vol. 128, No. 2, 2004, pp. 193-200. doi:10.1016/j.jpowsour.2003.09.075

[12] L. J. Yang, H. J. Yu, L. J. Jiang, L. Zhu, X. Y. Jian and Z. Wang, "Improved Anticorrosion Properties and Electrical Conductivity of $316 \mathrm{~L}$ Stainless Steel as Bipolar Plate for Proton Exchange Membrane Fuel Cell by Lower Temperature Chromizing Treatment," Journal of Power Sources, Vol. 195, No. 9, 2010, pp. 2810-2814. doi:10.1016/j.jpowsour.2009.11.018

[13] Y. Fu, G. Q. Lin, M. Hou, B. Wu, H. K. Li, L. X. Hao, Z. G. Shao and B. L. Yi, "Optimized Cr-Nitride Film on 316L Stainless Steel as Proton Exchange Membrane Fuel Cell Bipolar Plate,' International Journal of Hydrogen Energy, Vol. 34, No. 1, 2009, pp. 453-458. doi:10.1016/j.ijhydene.2008.09.104

[14] A. E. Fetohi, R. M. A. Hameed, K. M. El-Khatib and E. R. Souaya, "Ni-P and Ni-Co-P Coated Aluminum Alloy 5251 Substrates as Metallic Bipolar Plates for PEM Fuel Cell Applications," International Journal of Hydrogen Energy, Vol. 37, No. 9, 2012, pp. 7677-7688. doi:10.1016/i.ijhydene.2012.01.145

[15] Y. Hung, K. M. El-Khatib and H. Tawfik, "CorrosionResistant Lightweight Metallic Bipolar Plates for PEM Fuel Cells," Journal of Applied Electrochemistry, Vol. 35, No. 5, 2005, pp. 445-447. doi:10.1007/s10800-004-8350-6

[16] Y. Hung, K. M. El-Khatib and H. Tawfik, "Testing and Evaluation of Aluminum Coated Bipolar Plates of PEM Fuel Cells Operating at $70^{\circ} \mathrm{C}$," Journal of Power Sources, Vol. 163, No. 1, 2006, pp. 509-513. doi:10.1016/i.jpowsour.2006.09.013 